\title{
Experience of the MALA Bag in the Open Abdomen Management in an Obstetrical Intensive Care Unit
}

\author{
Experiência da Bolsa MALA no Tratamento do Abdomén Aberto \\ numa Unidade de Cuidados Intensivos Obstétricos
}

\author{
Ricardo Mauricio MALAGÓN REYES ${ }^{1}$, Luis Emilio REYES MENDOZA, María de Jesús ANGELES VÁZQUEZ¹, Hugo \\ MENDIETA ZERÓN ${ }^{1,2}$ \\ Acta Med Port 2013 Nov-Dec;26(6):699-704
}

\begin{abstract}
Introduction: Current indications for open abdomen management are damage control surgery, severe intra-abdominal sepsis, abdominal compartment syndrome, abdominal wall closure under tension and mass loss of the abdominal wall.

Objective: To describe the experience in open abdomen management using the MALA (mayor absorción de líquido abdominal [greater absorption of abdominal liquid]) bag at the Maternal-Perinatal Hospital Mónica Pretelini Saénz, Health Institute of the State of Mexico. Material and Methods: This was a bidirectional, descriptive and observational study. All patients with the diagnosis of open abdomen managed with the MALA bag admitted to the Obstetric Intensive Care Unit from February 2009 to June 2012 were included.

Results: From 25 cases identified in the period of the study, seven were eliminated for incomplete files, remaining 18 cases for the analysis. The mean age was 31.5 years. $78 \%$ of the patients were multigravidas, $50 \%$ of them with a history of 2 or more deliveries, $83 \%$ had a previous cesarean section and $78 \%$ were hysterectomized. Evisceration was present in one patient. The main indication for surgical management was damage control. One patient died and a second was transferred to another institution, the rest were discharged by clinical improvement. 12 patients (67\%) spent less than 14 days in the Obstetric Intensive Care Unit, only one patient required more than 30 days in the unit. Discussion: Halve the women who required this surgical alternative, were above 30 years of age. Stressing is the fact that from the 18 admitted patients, $14(78 \%)$ had undergone obstetric hysterectomy, with the etiology of uterine atony in most cases. Damage control surgery seems to be the most elective surgical option to use MALA bag followed by ACS and abdominal sepsis. Conclusion: The MALA bag can offer an economic and effective surgical option for the open abdomen management as well as a drainage technique.
\end{abstract}

Keywords: Abdomen/ surgery; Pregnancy Complications/ surgery; Abdominal Wound Closure Techniques; Mexico.

\section{RESUMO}

Introdução: As indicações atuais para a gestão de abdómen aberto são a cirurgia de controlo de danos, a abordagem de sepsis intraabdominal grave, a síndrome de compartimento abdominal, o encerramento da parede abdominal sob tensão e a perda de massa da parede abdominal.

Objetivo: Descrever a experiência em gestão e cirurgias de abdómen aberto usando a bolsa MALA (Maior Absorção de Líquido Abdominal).

Material e Métodos: Estudo descritivo, incluindo todos os doentes com o diagnóstico de abdómen aberto gerido com a bolsa MALA internados na Unidade de Cuidados Intensivos Obstétricos de Fevereiro de 2009 a Junho de 2012.

Resultados: Dos 25 casos identificados no período do estudo, sete foram eliminados por arquivos incompletos, permanecendo 18 casos para a análise. A média de idade foi de 31,5 anos. Setenta e oito por cento dos doentes eram multíparas, $50 \%$ com uma história de dois ou mais partos, $83 \%$ com uma cesariana anterior e $78 \%$ histerectomizadas, por atonia uterina, na maioria dos casos. A principal indicação para tratamento cirúrgico foi o controlo de danos. Uma doente morreu e uma segunda foi transferida para outra instituição, tendo as demais tido melhoria clínica. Doze doentes (67\%) permaneceram menos de 14 dias na Unidade de Cuidados Intensivos Obstétricos e apenas uma precisou de mais de 30 dias na unidade.

Conclusão: A bolsa MALA pode oferecer uma opção económica e eficaz para a gestão cirúrgica abdominal aberta, bem como uma técnica de drenagem.

Palavras-chave: Complicações na Gravidez/ cirurgia; Abdomén/ cirurgia; México.

\section{INTRODUCTION}

Current advances in open abdomen management are encouraging; however, the results do not show the same benefits to all patients. ${ }^{1-4}$ The abdominal closure should ideally allow abdominal viscera containment, protect against mechanical damage and prevent intestinal tissue drying, contamination of peritoneal cavity and peritoneal fluid loss. ${ }^{5}$ Today, the election of the open abdomen management is growing as surgeons become more familiar with its use; however, it is associated with high morbidity and mortality. ${ }^{4,6}$ Besides, the elective treatments of patients that pre- sent with any of the current indications for open abdomen management involves substantial costs to the institutions responsible for their care.

Current indications for this surgical option are: damage control surgery, severe intra-abdominal sepsis, abdominal compartment syndrome (ACS), abdominal wall closure under tension and mass loss of the abdominal wall. ${ }^{3}$ These diseases are presented with variable frequency in obstetrics, in which the benefits may include the prevention and treatment of intra-abdominal hypertension syndrome,

1. Maternal-Perinatal Hospital Mónica Pretelini Sáenz. Health Institute of the State of Mexico. Toluca. México.

2. Asociación Científica Latina A.C. (ASCILA) and Ciprés Grupo Médico S.C. (CGM). Toluca. México.

Recebido: 31 de Julho de 2013 - Aceite: 10 de Agosto de 2013 | Copyright @ Ordem dos Médicos 2013 
prevention of peritoneal cavity infection and ACS. ${ }^{7-11}$ Intraabdominal pressure (IAP) is a hemodynamic monitoring option in critically ill patients to avoid this syndrome. ${ }^{7}$

Until now, the open abdomen management involves many doubts. This is due to the fact that there is uncertainty regarding the most appropriate surgical technique. Among the options to treat this condition have been described vacuum systems, ${ }^{7-11}$ Bogota bag, ${ }^{3,5,7,11}$ close skin only technique, ${ }^{12}$ prosthetic materials, ${ }^{13}$ Wittman Patch, ${ }^{3,6}$ topical negative pressure (TNP), fascial closure, temporary abdominal closure, fascial dehiscence and deep wound dehiscence, ${ }^{14}$ cutaneous-adipose tissues detachment, ${ }^{15}$ modified Bogota bag (MBB), ${ }^{16}$ etc.

Among all the options to treat open abdomen there are three similar in cost/effectiveness: The Bogota bag, the subcutaneous polyethylene bag and the MALA (mayor absorción de líquido abdominal in the original spanish/greater absorption of abdominal liquid) bag (introducing). The first was implemented by Borráez in Colombia about 20 years ago, referring to a sterile bag fixed to the edges of the wound or aponeurosis. 2,17 The subcutaneous polyethylene bag was proposed in the National Medical Center Siglo XXI, Instituto Mexicano del Seguro Social (IMSS), placing a plastic bag beneath the peritoneum, covering the entire abdominal content and extracted by a small opening approximately 5 $\mathrm{cm}$ below the inferior angle of the wound, closing the skin over the plastic. 5,17 Our main objective was to describe the experience in the open abdomen management using MALA bag.

\section{MATERIAL AND METHODS \\ Design}

This was a bidirectional, descriptive and clinical study. Initially we proceeded to search the cases of open abdomen management in the statistical program database of the Maternal-Perinatal Hospital Mónica Pretelini Saénz (HMPMPS) from February 2009 to January 2012.

\section{Patients}

All women in the pregnancy-puerperal cycle with open abdomen managed with the MALA bag in the period of the study were included. Patients with incomplete files or previous pathology or abdominal wall defects were excluded.

\section{Sociodemographic and clinical data}

All variables were collected through a data-sheet developed by the researchers. Once selected, the files were reassessed to confirm the diagnosis reliability.

\section{Laboratory}

We measured hematic biometry (Advia 120, Bayer Health), glucose $(\mathrm{mg} / \mathrm{dl})$, cholesterol $(\mathrm{mg} / \mathrm{dl})$, high-density lipoproteins (HDL) $(\mathrm{mg} / \mathrm{dl})$, low-density lipoproteins (LDL) $(\mathrm{mg} / \mathrm{dl})$ and triglycerides $(\mathrm{mg} / \mathrm{dl})$ (Dimension $\mathrm{Rx} L \mathrm{Lax}$, Dade Behring).

\section{Intra-abdominal pressure}

We measured intra-abdominal pressure (IAP) with saline solution instillation $(50 \mathrm{cc})$ by urethral catheter.

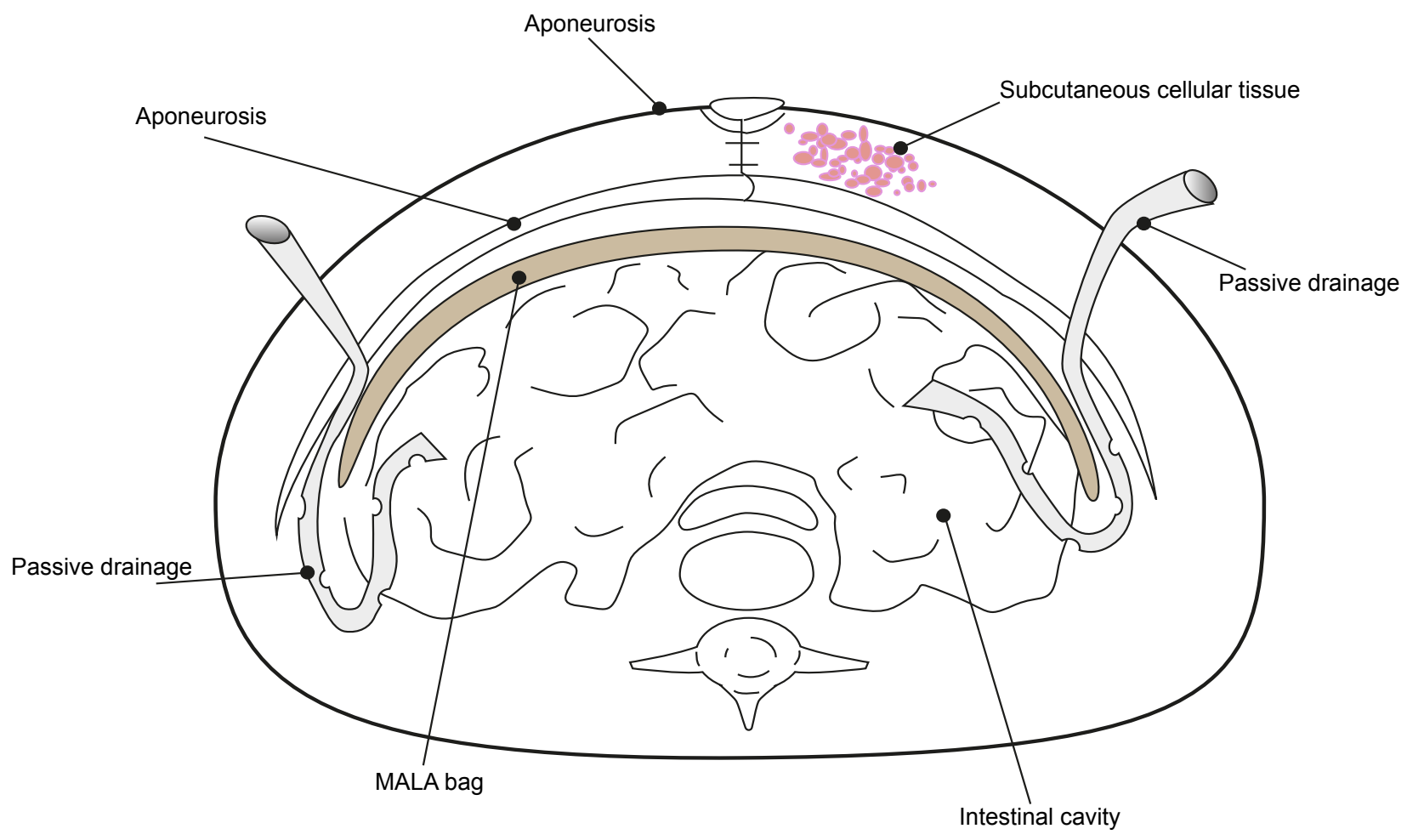

Figure 1 - Schematic representation of the MALA bag insertion. 
Table 1 - Clinical characteristics of the women treated with MALA bag $(n=18)$

\begin{tabular}{|c|c|c|c|c|}
\hline \multirow[t]{2}{*}{ Characteristic } & \multicolumn{2}{|c|}{ Distribution } & \multicolumn{2}{|r|}{ (mean \pm SD) [range] } \\
\hline & $\mathbf{v}$ & $\mathbf{F}$ & $\%$ & \\
\hline \multirow{2}{*}{ Age (years) } & $<30$ & 7 & 38.8 & \multirow{2}{*}{$31.5 \pm 5.1[19-37]$} \\
\hline & $\geq 30$ & 11 & 61.1 & \\
\hline \multirow{5}{*}{ Parity } & 0 & 6 & 33.3 & \multirow{5}{*}{$1.5 \pm 1.4[0-4]$} \\
\hline & 1 & 3 & 16.6 & \\
\hline & 2 & 5 & 27.7 & \\
\hline & 3 & 1 & 5.5 & \\
\hline & 4 & 3 & 16.6 & \\
\hline \multirow{2}{*}{$\begin{array}{l}\text { Gestational age at ICU admission } \\
\text { (weeks) }\end{array}$} & $\geq 37$ & 5 & 27.7 & \multirow{2}{*}{$36.1 \pm 4[28-39.3]$} \\
\hline & $<37$ & 13 & 72.2 & \\
\hline \multirow{5}{*}{ Days with MALA bag } & 2 & 2 & 11.1 & \multirow{5}{*}{$3.8 \pm 1.6[2-7]$} \\
\hline & 3 & 10 & 55.5 & \\
\hline & 4 & 1 & 5.5 & \\
\hline & 6 & 3 & 16.6 & \\
\hline & 7 & 2 & 11.1 & \\
\hline
\end{tabular}

ICU: intensive care unit, F: frequency, V: value.

\section{MALA bag}

The technique of the MALA bag is: Once solved the cause of the laparotomy, the MALA bag (a sterile bag for urine collection or for dialysis) is open in three corners, then is put above the bowel loops and the great omentum, trying to cover as much area as possible, with this we diminish the adherence formation. The MALA bag is externalized about $5 \mathrm{~cm}$ above the suprapubic limit and fixed with two non absorbable simple sutures. In this opening, a collection bag must be put to quantify the fluids (Fig. 1).

\section{Statistical analysis}

Data analysis was performed using Excel program. Frequency distribution tables were constructed for categorical variables, calculating measures of central trend and dispersion for quantitative variables.

\section{Ethical implications}

In accordance with Articles 96, 100 and 102 of the General Law of Health (Mexico), this study is classified as zero risk to participants and involves no procedures that endanger their health. This research was authorized by the Ethics and Research Committee of the HMPMPS (registration number: 2012-01-228) and we were adhered to the Helsinki recommendations.

\section{RESULTS}

During the study period, 1067 obstetric patients were admitted at the ICU. 25 records $(2.3 \%)$ in the database of the HMPMP fulfilled the entry criteria for this protocol, during the period considered for the study. Seven cases that were not able to complete data analysis were eliminated. In Table 1 we list the principal clinical characteristics of the studied population.

The age (mean \pm SD) of patients was $31.5 \pm 5.15$ years (range 37-19), similar to a case-control study conducted in
England (29.6 years, controls, 28.7 years) ${ }^{18}$ and to those described in a 12-year study conducted in the Netherlands (30 years), ${ }^{19}$ but older than in an Indian ICU study, which was 25.5 years. ${ }^{20}$

Average gestational age was $36.1 \pm 4.01$ weeks. Regarding the number of gestations, six women developed their third gestation (33\%), five patients $(28 \%)$ had their fourth pregnancy, those in their first, second and seventh pregnancy, each were two patients (11\%); and one patient (6\%) developed its sixth pregnancy.

Of all patients who have had vaginal deliveries, five patients had a history of five previous births (28\%), three patients $(17 \%)$ had a birth, similarly, three more women (17\%) had only one delivery, one participant (3\%) was primiparous, six patients (33\%) have failed vaginal obstetrical resolution.

Of the total population, the history of C-section was distributed as follows: the group with the highest percentage (50\%, 9 individuals) was that of one cesarean section followed by those with two C-sections (17\%, 3 participants), also with $17 \%$ was the group which has never been submitted to C-section, two patients (11\%) had a history of 3 cesareans and one woman (5\%) had four abdominal deliveries.

In a previous study carried out in Brazil, caesarean section was performed in $65.3 \%$ of patients who had their deliveries during the ICU stay. ${ }^{21}$ While in our study there were 5 women $(28 \%)$ in vaginal postpartum, 12 women $(67 \%)$ in post-cesarean puerperium and only one woman (5\%) was in post-abortion puerperium. When listing the presence of complications, 14 women (78\%), corresponding to more than three-quarters of the total, required hysterectomy due to severe obstetric hemorrhage. Evisceration was present in only one patient $(6 \%)$.

Considering the history of abortions, $50 \%$ of the participants had no previous abortion, seven patients $(39 \%)$ had 
Advantages Economical.

Economical.

Utility: skin closure.

It is required a second surgical intervention for abdominal wall plastia.

Complications include evisceration, intestinal fistulas and massive fluid drainage.
It is expected to form a controlled hernia. one previous abortion, and two patients (11\%) presented abortion on 2 occasions. No patient in the present study had over two abortions.

In relation to the $\mathrm{IAH}$, the patients were divided into five groups: a) three $(17 \%)$ with physiological IAP (0 to < $12 \mathrm{mmHg}$ ), b) seven (39\%) with grade I (12-15 $\mathrm{mmHg}), \mathrm{c})$ four $(22 \%)$ with grade II $(16-20 \mathrm{mmHg})$, d) three $(17 \%)$ with grade III (21-25 $\mathrm{mmHg})$ and e) one (5\%) with grade IV (> $25 \mathrm{mmHg}$ ). ACS (IAH higher than $20 \mathrm{mmHg}$ associated with any organ dysfunction), appeared in four individuals (22\%). The indications for MALA bag were: 14 patients (78\%) for damage control surgery, three patients (17\%) for ACS, and one patient $(5 \%)$ for abdominal sepsis. The average time of MALA bag use was of $3.8 \pm 1.6$ days (range $2-7$ ). On the first day the liquid quantification was of $1954 \pm 1739 \mathrm{ml}$.

The average hospital stay of these patients in the ICU was 12 days, with a minimum of five and a maximum of 30 days of hospitalization. Eight patients (32\%) underwent mechanical ventilation, with a mean of $171 \pm 201$ days. One patient was 28 days under mechanical support with a final evolution to decease.

Finally, 16 patients (89\%) were discharged for clinical improvement, one patient $(5.5 \%)$ had to be transferred to another ICU and one patient died.

\section{DISCUSSION}

The three indications adopted in our study for the open abdomen management: damage control surgery, ACS and abdominal sepsis corresponds to those described in the literature. ${ }^{13}$ The election of this technique is not for every woman but the particularities of the medical attention in our third level hospital implies a time-dependent survival for the patients as they come from small towns far away from Toluca City, which means several hours since the beginning of the obstetric complication until arriving to our hospital with the increased risk of bowel distension and abdominal wall oedema that may prevent tension-free closure forcing the surgeon to leave the abdomen open. ${ }^{22}$

Among the complications of open abdomen management there are short-term such as fistulas, residual abscess formation, secondary haemorrhage or long-term such as incisional hernia. These complications depend on the individual characteristics of the patient and the elected technique. In our study, we had a case of evisceration in a morbidly obese woman.

According to the literature, age is a risk factor predisposing to perinatal morbidity. ${ }^{23}$ In this regard, we observed that more than half of the women who required this surgical alternative, were above 30 years of age. Likewise, women with multiple pregnancies or multiple births, are at increased risk of obstetric complications. ${ }^{24}$ Moreover, caesarean section is itself a risk factor for placenta previa or placenta accreta and uterine rupture. In the present study, $78 \%$ of the patients were multiparous, only $22 \%$ had two or fewer pregnancies. Also noteworthy is the fact that $50 \%$ of patients had a history of 2 or more births, and only one was primiparous.

The need for more frequent obstetric hysterectomy as part of the consequences of complications in cesarean puerperal condition of our study, with 12 women (67\%), submitted to this surgery after cesarean section, coincided with reports on the issue. Stressing is the fact that from the 18 admitted patients, 14 (78\%) had undergone obstetric hysterectomy, with the etiology of uterine atony in most cases, data that corresponds to that reported by Mercier and Van de Velde. ${ }^{25}$

The global prevalence of $\mathrm{IAH}$, reaches $35 \%$. We found $\mathrm{IAH}$ as a constant variable, perhaps because pregnant women have inherent $\mathrm{IAH}$, even without perinatal morbidity. Specifically, we found that IAH was present in 15 patients $(83 \%)$ and four of them (22\%) developed ACS.

The odds ratio (OR) determination of each variable 
against a control group is beyond the scope of this study due to its design of case series report. Probably, in a comparative study, the number needed in each group to reach a power higher than $80 \%$ should be so high to be developed in a relatively short period of time in one unique ICU.

The open abdomen is not a safe surgical approach; complications ranging from electrolyte disturbances, enteric fistulas, intra-abdominal abscesses and giant abdominal muscle-aponeurotic defects development with their important functional and aesthetic consequences are common. In this case series report, evisceration complication of open abdomen management was present only in one patient (6\%).

At present, the benefits that arise with the open abdomen technique are best evidenced by the decreased range of mortality, compared with the closed treatment. In Germany, most commonly used treatments for open abdomen are staged abdominal lavage (87\%), commercial abdominal dressing system (82\%), planned ventral hernia (69\%), and other intra-abdominal dressings (e.g. vacuum pack $15 \%$, Bogota bag $5 \%) .{ }^{26}$ The Opsite sandwich or Bogota bag invariably leaks, and sometimes needs changing daily. VAC systems are not financially affordable. ${ }^{27}$ On the contrary, MALA bag is inexpensive and easy to apply, even more, has simplified the nursing of patients with an open abdomen, and has enabled us to reduce the frequency of a second surgical time. Even more, the drainage capacity of the MALA bag almost doubles that of two Penrose catheters. In the Table 2 we list the principal characteristics of three similar techniques for the open abdomen management: Bogota bag, polyethylene bag and MALA bag.

There is a lack of studies comparing the techniques to treat open abdomen, which supports the importance of the current report to introduce a novel option to be considered. The advantage of the current study is to have been performed in a third level hospital with strong expertise in

\section{REFERENCES}

1. Borráez OA. Abdomen abierto: la herida más desafiante. Rev Colomb Cir. 2008;23:204-9.

2. Brox-Jiménez A, Ruíz-Luque $V$, Torres-Arcos $C$, Parra-Membrives P, Díaz-Gómez D, Gómez-Bujedo L, et al. Experiencia con la técnica de la bolsa de Bogotá para el cierre temporal del abdómen. Cir Esp. 2007;82:150-4.

3. Iñaguazo SD, Astudillo AM. Abdomen abierto en la sepsis intraabdominal severa. ¿Una indicación beneficiosa? Rev Chil Cir. 2009;61:294300.

4. Sánchez-Lozada R, Ortiz-González J, Dolores-Velázquez R, Soto-Villagrán R, Gutiérrez-Vega R. Abdomen abierto vs cerrado en peritonitis grave por traumatismo. Estudio comparativo. Gac Med Mex. 2004;140:295-8.

5. de la Fuente-Lira M, Mendoza MV, Robledo-Ogazón F, Mier y Díaz J, Martínez-Ordaz JL, Blanco Benavides R. Cierre temporal de la pared abdominal con polietileno. Cir Ciruj. 2002;70:157-63.

6. Tavares-de la Paz LA, Andrade-de la Garza P, Gone-Fernández A, Sánchez-Fernández P. Abdomen abierto. Evolucion en su manejo. Cir Cir. 2008;76:177-86.

7. Carrillo-Esper R, Sosa García JO. Presión Intraabdominal: su importancia en la práctica clínica. Med Int Mex. 2010;26:48-62.

8. Forero JC, Rodríguez JA. Cirugía de abdomen abierto en gineco obstetricia: indicaciones, técnica y manejo. Rev Colomb Obstet Ginecol. 2005;56:155-65.

9. Malbrain ML, De laet IE. Intra-abdominal hypertension: evolving con- several methods to treat open abdomen, however, a clear disadvantage is the retrospective phase, also although a case series report could be of limited interest for most experts in obstetric hemorrhage, this type of article predominate in the scientific literature related to open abdomen management. ${ }^{14}$ For a more convincing argument in favor of the MALA bag use, it is required a randomized study contrasting at least two methods of open abdomen management.

\section{CONCLUSIONS}

In our case series study, the damage control surgery was the main indication for open abdomen, followed by ACS. With these data on, these indications seem to benefit from MALA bag use. Thus far, this surgical and drainage technique is economical as well as of easy placement and removal.

Finally, given the lack of consensus regarding optimal management strategies for the open abdomen, there is a need for prospective, multi-institutional studies to evaluate therapeutic approaches to treat this challenging problem. ${ }^{28}$

\section{ACKNOWLEDGMENTS}

Authors thank Kátia da Boit Martinello, Instituto de Pesquisas Ambientais e Desenvolvimento Humano, Capivari de Baixo - Santa Catarina, Brazil for helping us with the Portuguese abstract translation.

\section{CONFLICT OF INTEREST}

The authors have no competing interests to declare.

\section{FUNDING SOURCES}

This research received no specific grant from any funding agency in the public, commercial, or not for-profit sectors.

cepts. Crit Care Nurs Clin North Am. 2012;24:275-309.

10. Teicher EJ, Pasquale MD, Cipolle MD. Abdominal Compartment Syndrome. Operative Techniques Gen Surg. 2008;10:39-59.

11. Timoney MF, Zenilman ME. How we manage abdominal compartment syndrome. Contemp Surg. 2008;64:468-73.

12. Blackbourne LH. Combat damage control surgery. Crit Care Med. 2008;36:S304-10.

13. Benítez Valdez LV, Pirota MF, Sánchez CE, Gorodner A. Manejo de abdomen abierto y contenido con malla: técnica de Bogotá. Rev Posg Vla Cátedra Med. 2007;171:5-7.

14. Quyn AJ, Johnston C, Hall D, Chambers A, Arapova N, Ogston S, et al. The open abdomen and temporary abdominal closure systems-historical evolution and systematic review. Colorectal Dis. 2012;14:e429-38.

15. Drumond DA. Skin-adipose tissue detachment for laparotomy closure: a simple and effective technique for a complex problem. Rev Col Bras Cir. 2010;37:175-83.

16. Joglar F, Agosto E, Marrero D, Canario QM, Rodríguez P. Dynamic retention suture closure: modified Bogota bag approach. J Surg Res. 2010;162:274-8

17. Manterola C, Moraga J, Urrutia S. Contained laparostomy with a Bogota bag. Results of case series. Cir Esp. 2011;89:379-85

18. Waterstone M, Bewley S, Wolfe C. Incidence and predictors of severe obstetric morbidity: case-control study. BMJ. 2001;322:1089-93.

19. Keizer JL, Zwart JJ, Meerman RH, Harinck BI, Feuth HD, van RJ. Obstetric intensive care admissions: a 12-year review in a tertiary care 
centre. Eur J Obstet Gynecol Reprod Biol. 2006;128:152-6.

20. Karnad DR, Lapsia V, Krishnan A, Salvi VS. Prognostic factors in obstetric patients admitted to an Indian intensive care unit. Crit Care Med. 2004;32:1294-9.

21. Coelho MA, Katz L, Coutinho I, Hofmann A, Miranda L, Amorim M. Profile of women admitted at an obstetric ICU due to non-obstetric causes. Rev Assoc Med Bras. 2012;58:160-7.

22. Hirshberg A, Mattox KL. Planned reoperation for severe trauma. Ann Surg. 1995;222: 3-8.

23. Mbamara SU, Obiechina N, Eleje GU. An analysis of uterine rupture at the Nnamdi Azikiwe University Teaching Hospital Nnewi, Southeast Nigeria. Niger J Clin Pract. 2012;15:448-52.

24. ACOG Practice Bulletin: Clinical Management Guidelines for Obstetri-
cian-Gynecologists Number 76, October 2006: postpartum hemorrhage. Obstet Gynecol. 2006;108:1039-47.

25. Mercier FJ, Van d V. Major obstetric hemorrhage. Anesthesiol Clin 2008;26:53-66.

26. Herrle F, Hasenberg T, Fini B, Jonescheit J, Shang E, Kienle P, et al. Offenes abdomen 2009 umfrage zu behandlungsstrategien des offenen abdomens in Deutschland. Chirurg. 2011;82:684-90.

27. Campbell AM, Kuhn WP, Barker P. Vacuum-assisted closure of the open abdomen in a resource-limited setting. S Afr J Surg. 2010;48:114-5.

28. MacLean AA, O'Keeffe T, Augenstein J. Management strategies for the open abdomen: survey of the American Association for the Surgery of Trauma membership. Acta Chir Belg. 2008;108:212-8. 
Ricardo Mauricio MALAGÓN REYES, Luis Emilio REYES MENDOZA, María de Jesús ANGELES VÁZQUEZ, Hugo MENDIETA ZERÓN

\section{Experience of the MALA Bag in the Open Abdomen Management in an Obstetrical Intensive Care Unit Acta Med Port 2013:26:699-704}

Publicado pela Acta Médica Portuguesa, a Revista Científica da Ordem dos Médicos

Av. Almirante Gago Coutinho, 151

1749-084 Lisboa, Portugal.

Tel: +351218428 215

E-mail: submissao@actamedicaportuguesa.com

www.actamedicaportuguesa.com

ISSN:0870-399X | e-ISSN: 1646-0758

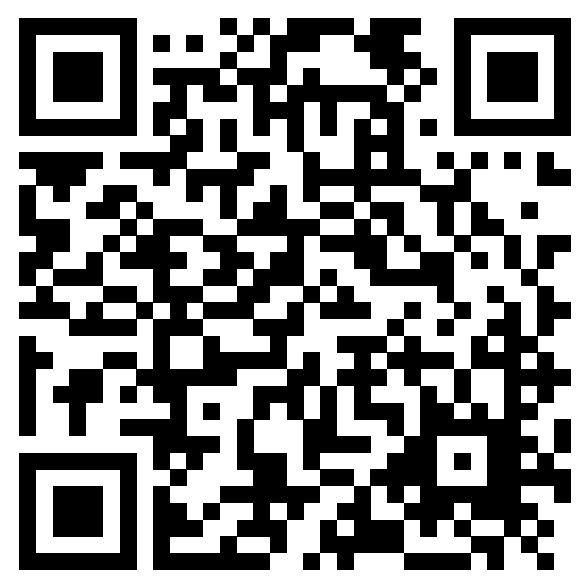

